\title{
How Do E-Venify Mandates Affect Unauthorized Immigrant Workers?
}

Pia M. Orrenius, Madeline Zavodny

Federal Reserve Bank of Dallas

Research Department

Working Paper 1403 


\title{
How Do E-Verify Mandates Affect Unauthorized Immigrant Workers?*
}

\author{
Pia M. Orrenius \\ Federal Reserve Bank of Dallas \\ 2200 N. Pearl St. \\ Dallas, TX 75201 \\ (214) 922-5747 \\ pia.orrenius@dal.frb.org \\ Madeline Zavodny \\ Agnes Scott College \\ 141 E. College Ave. \\ Decatur, GA 30030 \\ (404) 471-6377 \\ mzavodny@agnesscott.edu
}

\begin{abstract}
A number of states have adopted laws that require employers to use the federal government's E-Verify program to check workers' eligibility to work legally in the United States. Using data from the Current Population Survey, this study examines whether such laws affect labor market outcomes among Mexican immigrants who are likely to be unauthorized. We find evidence that E-Verify mandates reduce average hourly earnings among likely unauthorized male Mexican immigrants while increasing labor force participation and employment among likely unauthorized female Mexican immigrants. In contrast, the mandates appear to lead to better labor market outcomes among workers likely to compete with unauthorized immigrants. Employment and earnings rise among male Mexican immigrants who are naturalized citizens in states that adopt E-Verify mandates, and earnings rise among U.S.-born Hispanic men.
\end{abstract}

Keywords: unauthorized immigration, immigration policy, electronic verification, E-Verify JEL Classification: J15; J31; J61

\footnotetext{
* Madeline Zavodny is corresponding author. The views expressed here are solely those of the authors and do not reflect those of the Federal Reserve Bank of Dallas or the Federal Reserve System. We thank Melissa LoPalo for excellent research assistance. We also thank Todd Sørensen, Julie Hotchkiss, and seminar participants at the University of Texas at Dallas and the 2013 Southern Economic Association meetings for helpful comments.
} 


\section{How Do E-Verify Mandates Affect Unauthorized Immigrant Workers?}

\section{Introduction}

E-Verify mandates have become widespread since the mid-2000s, when many states began crafting their own immigration laws. States that have implemented the mandates require employers to check that the workers they hire can be legally employed in the United States. The mandates are intended to curb hiring of undocumented immigrants, a group that is estimated to make up over 5 percent of the U.S. labor force (Passel and Cohn 2009).

E-Verify has its roots in the Immigration Reform and Control Act (IRCA) of 1986, which aimed to largely end unauthorized immigration through three means: granting amnesty to undocumented immigrants who met specific requirements, increasing funding for the Border Patrol, and requiring that workers be legally authorized to work in the United States. Although 2.7 million migrants received legal permanent residence under IRCA, unauthorized immigration soon resumed. By 2007, before the start of the Great Recession, the unauthorized immigrant population had swelled to 12.2 million. The recession, combined with stricter border and interior enforcement, caused the population to drop to 11.3 million in 2009 (Passel, Cohn, and GonzalezBarrera 2013).

IRCA required that workers present documents verifying their eligibility to work legally in the United States and imposed civil and criminal penalties on employers who knowingly hired or continued to employ unauthorized workers. Wages fell for likely unauthorized immigrants in the period soon after IRCA was adopted (Bansak and Raphael 2001). However, this wage effect may not have persisted for long, particularly for low-skilled unauthorized immigrants (Lofstrom, Hill, and Hayes 2013). Workers and employers alike quickly learned that the law was easily circumvented. Falsified work authorization documents were readily available, and employers 
needed only to examine documents, not verify their authenticity. Moreover, the government rarely imposed penalties for hiring unauthorized workers on employers, and it conducted worksite enforcement randomly instead of targeting industries most likely to employ immigrants (Reyes, Johnson, and Van Swearingen 2002). Attempts to increase enforcement often faced political opposition (Hanson 2006).

This lax system began to change in the mid-1990s. The Clinton administration conducted worksite raids that resulted in thousands of arrests of unauthorized immigrants. In response to complaints, the administration shifted its focus to employer audits targeting the meatpacking industry. It abandoned that effort after a political backlash (Suskin et al. 2006). Efforts to increase interior enforcement resumed after the terrorist attacks on September 11, 2001, heightened security concerns. The Social Security Administration (SSA) expanded its "nomatch" letter program that notified employers when workers' Social Security numbers were invalid or the name submitted with a number did not match the name for that number in SSA records. The Bush administration launched a series of high-profile worksite raids of large businesses that were believed to employ unauthorized workers and expanded the Basic Pilot program, which allowed employers to check the validity of workers' documents. ${ }^{1}$ The Obama administration later shifted the focus from worksite raids to audits of employers' records and, in September 2009, began requiring some federal contractors and subcontractors to verify the employment eligibility of new hires and of existing workers assigned to a covered federal contract.

This increased worksite enforcement was too little or came too late for some states. Between 2006 and 2012, 19 states passed laws or had executive orders that required employers

\footnotetext{
${ }^{1}$ In 2007, Basic Pilot was renamed E-Verify. It became available to employers in California, Florida, Illinois, New York, and Texas in 1997, to Nebraska in 1999, and to employers in all states in 2003. Since 2011, individuals have been able to use E-Verify Self Check to check their own employment eligibility.
} 
to verify workers' employment eligibility. In some states, these policies apply only to some or all parts of the public sector-government agencies - or to businesses with government contracts. In eight states, the mandates are universal - they apply to all employers. Appendix Table 1 lists the states with universal mandates and the dates the policies were adopted and were implemented, or first became effective. ${ }^{2}$ In some states, the mandates phase in by employer size, applying first to employers with more than a certain number of workers and eventually applying to smaller employers.

The main goal of employment verification mandates is to deter the hiring of unauthorized immigrants. The mandates' supporters typically have additional implicit goals: to discourage unauthorized immigrants from remaining in or moving to states that adopt the mandates, and to improve labor market opportunities for U.S. natives and legal immigrants who may compete with unauthorized immigrants for jobs. The mandates aim to accomplish these goals by making it difficult for unauthorized immigrants to find work with employers who comply with the law. In some states, employment verification mandates are accompanied by other anti-unauthorized immigrant measures, such as "show me your papers" requirements that require law enforcement officers to check immigration status during traffic stops and other interactions. ${ }^{3}$

The state employment verification mandates that we examine require employers to use EVerify. E-Verify is a free online system created and managed by the federal government. Employers enter the information on the employment eligibility form ("Form I-9") that the 1986 IRCA requires new hires to complete, and E-Verify compares that information with SSA and, if

\footnotetext{
${ }^{2}$ We only list and examine policies that require universal use of E-Verify. A few states have policies that allow employers to satisfy employment eligibility requirements by other means, such as keeping a copy of the federal I-9 employment verification form. We rely on analysis by Troutman Sanders, a large law firm, to code state policies (see http://www.troutmansanders.com/immigration/).

${ }^{3}$ For an examination of the effect of $287(\mathrm{~g})$ programs, which delegate authority for immigration enforcement to state or local law enforcement officers, see Bohn and Santillano (2011) and Parrado (2012).
} 
needed, Department of Homeland Security (DHS) records. If there is a discrepancy, the employer is notified of a tentative nonconfirmation and is told to notify the worker, who then has 10 federal work days to contest the discrepancy. During those 10 days, the employer cannot fire the worker because of the discrepancy; however, the employer must fire the worker if the discrepancy is not resolved after that period. Employers are not allowed to ask applicants about their employment eligibility or verify their eligibility before making them a job offer.

Unauthorized workers can pass E-Verify only by committing identity fraud—-supplying another person's valid Social Security number and name. In response to this concern, DHS recently added a photo matching tool and now requires the employer to verify that the photo in E-Verify is identical to the photo the employee presented when completing Form I-9, when possible. ${ }^{4}$

This study examines how state employment verification mandates affect labor market outcomes among immigrants who are likely to be unauthorized. We also look at effects among workers who are likely to compete in the labor market with unauthorized immigrants. We focus on universal mandates since relatively few unauthorized immigrants are likely to work for government agencies and there is no way to distinguish between those who work for a government contractor and those who do not.

The next section explains the potential effects of employment verification mandates and previous research findings. We then discuss the data, followed by our empirical methodology and findings. The results indicate that E-Verify mandates have a negative impact among likely unauthorized Mexican immigrants, particularly men, while benefiting workers who are likely to

\footnotetext{
${ }^{4}$ An evaluation by Westat (2009) concluded that E-Verify authorized 54 percent of workers it was supposed to reject, mainly because of document fraud. In response, DHS added photo matching for permanent resident cards and employment authorization documents in December 2009 and for U.S. passports in September 2010. However, driver's licenses are currently not included in the DHS database; the overwhelming majority of workers present a driver's license when completing Form I-9 (Rosenblum 2011).
} 
compete with unauthorized immigrants in the labor market. The results thus suggest that these laws are at least partially successful in achieving their supporters' goals.

\section{Potential Effects of E-Verify Mandates and Previous Findings}

The primary effect of E-Verify mandates should be to reduce the number of unauthorized immigrants who are employed in a state via reductions in both labor demand and labor supply. Employers should screen hires for employment eligibility, and some unauthorized workers who cannot find work or are afraid of being flagged by E-Verify are likely to drop out of the labor force or move to a state without mandates. However, there are several complications: not all employers may comply with a mandate; a mandate may cover only certain industries, resulting in a reallocation of unauthorized immigrant workers across industries but not a decrease in their total number; or unauthorized immigrants may shift from the formal sector to the informal sector, becoming self-employed workers instead of wage-and-salary employees.

Empirical studies report evidence consistent with the expected employment and population effects. Bohn, Lofstrom, and Raphael (2013) find that the number of non-U.S. citizen Hispanics living in Arizona fell after that state adopted a universal mandate in 2007. Good (2013) finds that omnibus anti-unauthorized immigrant state laws, most of which include a universal mandate, resulted in a 24 percent decrease in the population of likely unauthorized immigrants, and a 10 to 20 percent decrease in employment of likely unauthorized immigrants. Amuedo-Dorantes and Bansak $(2012,2013)$ find that the employment rate fell among likely unauthorized immigrants in states that adopted mandates, and there were shifts in the distribution of likely unauthorized immigrant workers across industries. Bohn and Lofstrom (2013) conclude 
that Arizona's universal mandate reduced the wage-and-salary employment rate among non-U.S. citizen Hispanics in that state and increased their self-employment rate.

The expected effect of E-Verify mandates on unauthorized immigrant workers' wages is less clear than the expected effect on employment. Reductions in labor demand for unauthorized workers will result in lower wages for those workers, whereas reductions in labor supply will push wages up, assuming that some employers continue to hire such workers. Crowding of unauthorized workers into sectors not covered by a mandate should reduce wages in those sectors.

There is less evidence on the wage impacts than on employment and population impacts. Amuedo-Dorantes and Bansak (2012) report that adoption of universal mandates boosts wages among female likely unauthorized immigrants while implementation of universal mandates lowers wages among male likely unauthorized immigrants. They speculate that the gender difference arises from men being more likely to work in covered sectors and hence more exposed to a reduction in labor demand than women, who are more likely to work in private households.

E-Verify mandates may have general equilibrium effects on employment and wages among other groups of workers. Complying with the mandates is costly. Employers must enter new hires' data into the federal database. In sectors that typically have large shares of unauthorized workers, the mandates have reportedly led to higher vacancies and higher recruiting costs (Loten, Needleman, and Janofsky 2013). These higher costs to employers could result in lower employment and wages for all workers (Stark and Jakubek 2012). Alternatively, employment and wages may fall for workers who are complementary to unauthorized immigrant workers but rise for workers who are substitutes for unauthorized immigrant workers. 
Previous findings on the effect on other groups of workers are mixed. Amuedo-Dorantes and Bansak (2013) find a positive effect of E-Verify mandates in various states on the employment rate of low-education, non-Hispanic U.S-born men and women, and a positive effect on men's wages. Bohn and Lofstrom (2013) find no evidence of spillovers effects on competing low-skilled groups' wage-and-salary employment rates or self-employment rates in Arizona. Good (2013) finds that omnibus anti-unauthorized immigrant laws have a negative effect on employment among low-education U.S.-born Hispanics and low-education Hispanic naturalized U.S. citizens.

E-Verify also may have general equilibrium effects via family-based decisions. People may enter or exit the labor force based on their spouse's, or other family members', earnings and employment. If men's earnings or employment worsen as a result of E-Verify mandates, women's labor force participation rate may increase as some wives enter the labor force, for example. Previous research has not explicitly examined the possibility of such effects.

\section{This Study's Contribution}

The mixed results of previous studies motivate our study's examination of E-Verify mandates on employment and earnings among likely unauthorized immigrants and on workers who are likely to compete with unauthorized immigrants in the labor market. We add to previous research a comprehensive examination of the effects of universal E-Verify mandates through the end of 2012. This allows us to examine effects in more states than previous research. We also examine effects on unemployment, labor force participation, and turnover-labor market outcomes not examined in previous research. E-Verify mandates may affect unemployment and labor force participation by causing workers to enter or exit the labor market in response to 
changes not only in their own labor market opportunities but also to changes in their family members' labor market opportunities.

An interesting, hitherto-unexamined facet of E-Verify laws is that they apply only to newly hired workers. With the exception of government contractors, employers are not required to verify the employment eligibility of current employees. Indeed, anti-discrimination laws may bar them from doing so. E-Verify mandates therefore may trap unauthorized immigrants into their current jobs, reducing their job mobility and their bargaining power for higher wages. At the same time, the mandates may boost job mobility among competing workers by enabling them to move into better jobs.

This study therefore also examines whether E-Verify laws reduce turnover, which we define as employer-to-employer transitions among workers. ${ }^{5}$ Employer-to-employer flows are a major source of labor market transitions in the labor market. For the labor market as a whole, employer-to-employer flows are more than twice as large as employment-to-unemployment flows and represent almost 40 percent of new jobs (Fallick and Fleischman 2004; Moscarini and Thomsson 2007). Hotchkiss and Quispe-Agnoli (2013) suggest that likely unauthorized immigrants have a higher probability of separating from their employers than likely documented workers, but previous research has not examined how E-Verify mandates affect workers' labor market transitions.

\footnotetext{
${ }^{5}$ We also examined whether the mandates have a differential earnings impact on newly-hired workers than on workers who remain with the same employer. However, power in these specifications is very low since less than 4 percent of likely unauthorized immigrants in the sample live in states with E-Verify mandates and only 3 percent switch employers. We did not find any significant difference in the estimated effect of E-Verify mandates on the earnings of workers who switched employers and those who remained with the same employer.
} 


\section{Data}

We use data from the Current Population Survey (CPS) during the period 2002-2012 to examine the effect of state-level E-Verify mandates. The CPS is a large-scale survey conducted monthly by the Census Bureau for the Bureau of Labor Statistics. The CPS is the primary source of labor force statistics in the United States. Housing units (e.g., addresses) are surveyed for four consecutive months, out of the sample for eight months, and then back in the sample for four more consecutive months. Every month, the CPS asks about the labor force status of noninstitutionalized civilians aged 16 and older. We use those responses to examine employment, unemployment, and labor force participation among people aged 20-64. In addition to looking at employment overall, we distinguish between wage-and-salary employment and self employment in some specifications since E-Verify mandates do not apply to the self employed.

The CPS contains some information about job mobility. People who were interviewed the previous month and were employed during both the previous month and the current month are asked whether they still work for the same employer. We use those responses to categorize people as workers who switched employers or not. Because this question in the CPS requires knowing people's employer last month, responses are only available for survey waves 2-4 and 68 for people who remain in the CPS (people who do not move). All of our employment analysis is therefore limited to those survey waves. ${ }^{6}$ Our analysis of employer-to-employer transitions is further limited to people who were employed in both the previous and the current month.

The CPS asks employed participants about their earnings during survey waves 4 and 8 (the "outgoing rotation groups"). We focus on hourly earnings, deflated using the consumer price

\footnotetext{
${ }^{6}$ As discussed below, E-Verify mandates may affect whether people move. The CPS does not follow individuals if they move housing units. Someone who moves into a housing unit surveyed by the CPS would be included in our sample.
} 
index for urban workers. ${ }^{7}$ Because of concerns about the imputation procedure for immigrants versus U.S. natives (Bollinger and Hirsch 2006), we do not include workers with imputed earnings in the earnings analysis. An important caveat is that the earnings data do not include self-employed workers. Bohn and Lofstrom (2013) indicate that median earnings are lower among potential unauthorized immigrants who are self-employed than among those who are wage and salary workers. If mandates increase unauthorized immigrants' self employment, our results are likely to underestimate any negative impact of mandates on their earnings.

We focus on immigrants who are particularly likely to be unauthorized. Immigrants are defined as people who are not U.S. citizens at birth. Passel and Cohn (2009) indicate that immigrants who have low educational attainment and are from Latin America, particularly Mexico, are disproportionately unauthorized; at least half of Mexican immigrants are believed to be unauthorized. We categorize immigrants who have at most a high school diploma, are from Mexico, and are not naturalized U.S. citizens as likely unauthorized immigrants. ${ }^{8}$ Although not all immigrants in this group are unauthorized immigrants, a high share of them are. Any differences we find between likely unauthorized immigrants and other groups are likely to be understated since the group of likely unauthorized immigrants includes immigrants who are legally present in the United States.

We compare likely unauthorized immigrants with three groups: low-education Mexican immigrants who report being naturalized U.S. citizens; low-education U.S.-born Hispanics, and low-education U.S.-born white non-Hispanics. ${ }^{9}$ All of the analysis below is stratified on sex

\footnotetext{
${ }^{7}$ For workers not paid on an hourly basis, we use weekly earnings divided by usual weekly hours as hourly earnings.

${ }^{8}$ Surveys like the CPS include unauthorized immigrants but likely undercount them (Hanson 2006; Passel, Cohn, and Gonzalez-Barrera 2013).

${ }^{9}$ Some immigrants who report being naturalized U.S. citizens may misreport their status. This would bias any estimates for this group toward the estimates for likely unauthorized immigrants.
} 
since sex differences in labor force outcomes tend to be different for immigrants than for U.S. natives. In addition, likely unauthorized immigrant men and women tend to work in very different industries, with men heavily concentrated in construction and women in private households, which may lead to sex differences in the effects of E-Verify mandates.

Table 1 reports sample means. Several patterns are worth noting. Likely unauthorized male immigrants are more likely to be employed and to be in the labor force than the other three groups we examine, while likely unauthorized female immigrants are less likely to be employed or in the labor force. Among both men and women, likely unauthorized immigrants earn considerably less than the three other groups. Likely unauthorized immigrants are more likely to have switched employers since the last month than the other three groups. Likely unauthorized immigrants are more likely that the other three groups to live in states that have adopted a universal E-Verify mandate.

\section{Methodology}

We examine the effect of the E-Verify mandates on labor market outcomes using ordinary least squares (OLS) regression models of the basic form

$$
\begin{aligned}
\text { Outcome }_{\text {ist }}=\alpha & +\beta_{1} \text { Mandate }_{\mathrm{st}}+\beta_{2} \text { Characteristics }_{\text {ist }}+\beta_{3} \text { Cycle }_{\mathrm{st}} \\
& + \text { State }_{\mathrm{s}}+\text { Time }_{\mathrm{t}}+\text { Trend }_{\mathrm{s}}+\varepsilon_{\text {ist }}
\end{aligned}
$$

where $i$ indexes individuals, $s$ indexes states, and $t$ indexes time. The dependent variable is the either a dummy variable (for employment, unemployment, labor force participation, and switching employers) or the natural log of real hourly earnings. Mandate is a dummy variable 
indicating whether a worker lives in a state that has adopted a universal mandate. ${ }^{10}$

Characteristics is controls for individual characteristics that are likely to be related to labor market outcomes. These include age, measured here as a quartic; marital status, measured as married, separated/divorced/widowed, or never married; number of own children living in the household; and a dummy variable for not having a high school degree. For samples of immigrants, years in the U.S. and its square are included as well. Cycle is four controls for statelevel business cycle conditions: the average unemployment rate during the previous three months; the log of real state GDP per capita during the previous year; the log of real state government expenditures per capita during the previous year; and the average number of housing permits and of housing starts during the previous three months. The last two variables are proxies for the level of construction activity in a state and are included because construction is an important employment sector for unauthorized immigrant men. Results for the estimated Characteristics and Cycle variables are not shown here but are available on request.

The regressions include state and time fixed effects that control for unobservable state- or time-specific factors that affect earnings. The time fixed effects are separate sets of year and month dummy variables. The month fixed effects control for any seasonality while the year fixed effects capture the national business cycle or other changes common to all states. The regressions also include state-specific linear time trends to control for underlying trends. We caution that these trend variables may capture part of any effect of mandates since most mandates coincided with the recession and a general downward trend in employment, labor force participation, and

\footnotetext{
${ }^{10}$ The results are qualitatively similar but typically closer to zero and with larger standard errors if we use implementation dates instead of adoption dates. This suggests that employers adapt to the laws between the time they are adopted and the time they become effective.
} 
earnings. ${ }^{11}$ The regressions also include survey wave fixed effects. The data are weighted using the CPS final weights (the earnings weights are used in the earnings regressions). The estimated standard errors are clustered at the state level.

Our identification scheme compares labor market outcomes in states that adopt an EVerify mandate with states that do not adopt a mandate. Because the regressions include state fixed effects, year fixed effects, and state-specific time trends, the estimated coefficients on Mandate measure whether labor market outcomes changed within a state after it adopted a mandate, relative to the changes over time in states that have not (yet, in some cases) adopted a mandate. This approach assumes that whether a state adopts a mandate is unrelated to factors that affect labor market outcomes, controlling for business cycle conditions in that state, or that adoption of mandates is exogenous.

\section{Results}

Table 2 reports the regression results for likely unauthorized Mexican immigrants. Among men, E-Verify mandates appear to reduce hourly earnings by about 8 percent. Mandates do not significantly affect whether men are employed overall, employed as wage-and-salary workers, self employed, unemployed, or in the labor force. Among women, E-Verify mandates raise employment and labor force participation by about 3.5 percentage points. This result is the opposite of the expected effect of E-Verify mandates but makes sense in the context of family decision making — as men's earnings go down, wives may enter the labor market as secondary

\footnotetext{
${ }^{11}$ State-specific time trends may absorb the variation needed to identify the wage effects of employment verification mandates much like they have been shown to do in other contexts, such as the minimum wage literature (see Neumark, Salas, and Wascher 2013).
} 
earners. ${ }^{12}$ More than 6 percent of unauthorized immigrant women who are employed work in private households, which may shield them from the effects of E-Verify mandates relative to unauthorized immigrant men. For both sexes, E-Verify mandates do not significantly affect whether likely unauthorized workers switch employers.

Our failure to find significant negative employment effects among likely unauthorized immigrants is at odds with previous research that finds negative employment effects. However, Good (2013) examines employment levels, not employment rates. If people who lose their jobs leave states that have adopted E-Verify mandates, the employment rate may remain the sameor even increase - among those remaining in those states. Bohn and Lofstrom (2013) report a negative effect of Arizona's E-Verify mandate on the wage-and-salary employment rate in that state, whereas our analysis examines eight states that have adopted E-Verify mandates. The effects in the other states may be different from those in Arizona. Alternatively, unauthorized immigrants' employment may have changed nationwide as more states adopted E-Verify mandates. Employers with operations in multiple states who had to begin verifying new hires' employment eligibility in one state may have begun verifying eligibility in all states in which they operate. Such a response would reduce the ability of our cross-state, over-time comparison to identify the effect of E-Verify mandates. Amuedo-Dorantes and Bansak $(2012,2013)$ find significant negative employment effects in a similar cross-state, over-time comparison but using a shorter time period than ours (2004-2011 versus 2002-2012). ${ }^{13}$

Before turning to whether the effects of E-Verify mandates on other groups, we examine whether the effects differ for long-term U.S. residents who are likely unauthorized immigrants

\footnotetext{
${ }^{12}$ Regressions stratified by women's marital status do not indicate a significant difference between married and unmarried women or between women married to likely unauthorized immigrant men and those married to other groups of men.

${ }_{13}^{13}$ In addition, all previous research examines low-education, non-naturalized immigrants from Mexico and all of Latin America, not just from Mexico.
} 
versus more recent arrivals. Table 3 shows results for stratifying the sample of likely unauthorized Mexican immigrants by whether they report having arrived in the United States within the last 10 years or 10 or more years ago. Men who arrived within the last 10 years are about 4 percentage points more likely to be employed and 3 percentage point less likely to be unemployed in states that have adopted an E-Verify mandate (column 1). Earnings losses are concentrated among men who arrived 10 or more years ago and are substantial, about 14 percent (column 3).

The positive employment impact among relatively recent arrivals is surprising but could be driven by selection. One potential explanation is that recently arrived men move away fromor do not go to- states that adopt an E-Verify mandate. Those who do stay in or go to those states are those who have managed to find or keep jobs there, resulting in a higher employment rate and lower unemployment rate in those states. Meanwhile, longer-term male residents who have put down roots and are less mobile experience earnings losses. Labor force participation and employment increase by about 5 percentage points among longer-term female residents (column 4) as men's earnings fall.

Although E-Verify mandates target unauthorized workers, they are likely to affect authorized workers as well. Workers who compete closely with unauthorized immigrants, such as low-education naturalized citizens and low-education natives, may benefit from the mandates. Table 4 shows the regression results for low-education Mexican immigrants who are naturalized U.S. citizens, low-education U.S.-born Hispanics, and low-education U.S.-born white nonHispanics.

The results indicate that some groups of competing male workers experience better labor market outcomes in states that adopt an E-Verify mandate. Employment and wage-and-salary 
employment rates and earnings increase among Mexican men who are naturalized U.S. citizens while self employment decreases (column 1). Earnings also increase among U.S.-born Hispanics, although unemployment increases as well (column 3). Unemployment can rise if workers perceive there to be more job opportunities and enter the labor force to search for employment. Non-Hispanic whites appear to be unaffected by E-Verify mandates, as are women in all three groups examined here. Unauthorized female immigrant workers are heavily concentrated in the secondary labor market (Cobb-Clark and Kossoudji 2000), which likely reduces how much they compete with other groups of women in the labor market. Non-Hispanic white male U.S. natives also may compete relatively little with unauthorized immigrants; if there are effects on those who do, they appear to be swamped by null effects on others.

\section{Conclusion}

A growing number of states require employers to verify workers' employment eligibility. Using data from 2002-2012, we find that universal E-Verify mandates appear to reduce hourly earnings by about 8 percent among male Mexican immigrants who are likely to be unauthorized, and this effect is concentrated among long-term U.S. residents. We do not find evidence that EVerify mandates reduce employment among likely unauthorized Mexican immigrants. On the contrary, women's employment increases in states that adopt E-Verify mandates. Lower earnings among men may induce some women to enter the labor market, while men may move away from states that adopt E-Verify mandates, cushioning the disemployment impact. Taken as a whole, the results indicate that E-Verify mandates to date are largely successful in achieving the goal of worsening labor market outcomes among unauthorized immigrants. 
Another goal of E-Verify mandates is to improve labor market outcomes for U.S. natives who may compete with unauthorized immigrants. We find some evidence that the laws achieve this objective, although positive effects are more prominent for Mexican immigrants who are naturalized U.S. citizens than for U.S.-born Hispanics. The adoption of E-Verify mandates does not appear to affect labor market outcomes among non-Hispanic whites either positively or negatively.

There are several caveats to our results. Migration to other states may reduce the impact of E-Verify mandates. In addition, there are a number of shortcomings with regard to what we know about employment eligibility verification mandates. We are unable to identify mandates that are strictly enforced from those that are merely "on the books." We do not know the extent of federal audits and other enforcement activities, which may be correlated with state mandates. We also are unable to examine the extent of E-Verify use in states that have not adopted mandates. Corporations with nationwide operations that implement E-Verify in one state may decide to extend that corporate policy to other states.

Despite these limitations, this study offers new evidence on the effects of E-Verify mandates. In particular, we fail to find evidence of significant negative employment effects among likely unauthorized Mexican immigrants, although we do find evidence of sizable negative earnings effects among men. If more states implement employment verification, unauthorized workers will likely have even lower wages and may not be able to avoid disemployment effects by moving to a state that does not have a mandate in place. This suggests E-Verify can be a powerful interior enforcement tool but could also lead to higher poverty and more social assistance needs among the unauthorized immigrant population. E-Verify mandates might be used more effectively and with fewer unintended consequences as part of a 
comprehensive immigration reform where they would be a deterrent to future unauthorized immigration. 


\section{References}

Amuedo-Dorantes, Catalina, and Cynthia Bansak. 2012. The labor market impact of mandated employment verification systems. American Economic Review: Papers \& Proceedings 103:5438 .

Amuedo-Dorantes, Catalina, and Cynthia Bansak. 2013. Employment verification mandates and the labor market outcomes of likely unauthorized and native workers. IZA discussion paper no. 7419.

Amuedo-Dorantes, Catalina, and Fernando A. Lozano. 2011. On the effectiveness of SB 1070 in Arizona. Unpublished paper, San Diego State University.

Bohn, Sarah, and Magnus Lofstrom. 2013. Employment effects of state legislation. In Immigration, poverty, and socioeconomic inequality, edited by David Card and Steven Raphael. New York: Russell Sage Foundation, pp. 282-314.

Bohn, Sarah, Magnus Lofstrom, and Steven Raphael. 2013. Did the 2007 Legal Arizona Workers Act reduce the state's unauthorized immigrant population? Review of Economics and Statistics. In press.

Bohn, Sarah, and Robert Santillano. 2011. Do local immigration laws impact employment and wages? Evidence from the 287(g) program. Unpublished paper, Public Policy Institute of California.

Bollinger, Christopher R., and Barry T. Hirsch. 2006. Match bias from earnings imputation in the Current Population Survey: The case of imperfect matching. Journal of Labor Economics 24:483-519.

Cobb-Clark, Deborah A., and Sherrie A. Kossoudji. 2000. Mobility in El Norte: The employment and occupational changes of unauthorized Latin American women. Social Science Quarterly 81:311-24.

Fallick, Bruce, and Charles A. Fleischman. 2004. Employer-to-employer flows in the U.S. labor market: The complete picture of gross worker flows. Finance and Economics Discussion Series paper no. 2004-34, Federal Reserve Board.

Good, Michael. 2013. Do immigrant outflows lead to native inflows? An empirical analysis of the migratory responses to US state immigration legislation. Applied Economics 45:4275-97.

Hanson, Gordon H. 2006. Illegal migration from Mexico to the United States. Journal of Economic Literature 44:869-924.

Hotchkiss, Julie L., and Myriam Quispe-Agnoli. 2013. The expected impact of state immigration legislation on labor market outcomes. Journal of Policy Analysis and Management 32:34-59. 
Lofstrom, Magnus, Laura Hill, and Joseph Hayes. 2013. Wage and mobility effects of legalization: Evidence from the New Immigrant Survey. Journal of Regional Science 53:171-97.

Loten, Angus, Sarah E. Needleman, and Adam Janofsky. 2013. Small business has a beef with E-Verify. The Wall Street Journal, 25 July, p. B6.

Moscarini, Giuseppe, and Kaj Thomsson. 2007. Occupational and job mobility in the US. Scandinavian Journal of Economics 109:807-36.

Neumark, David, J.M. Ian Salas, and William Wascher. 2013. Revisiting the minimum wageemployment debate: Throwing out the baby with the bathwater? NBER Working Paper No. 18681.

Parrado, Emilio A. 2012. Immigration enforcement policies, the economic recession, and the size of local Mexican immigrant populations. The ANNALS of the American Academy of Political and Social Science 641:16-37.

Passel, Jeffrey, and D'Vera Cohn. 2009. A Portrait of unauthorized immigrants in the United States. Pew Hispanic Center. http://www.pewhispanic.org/2009/04/14/a-portrait-ofunauthorized-immigrants-in-the-united-states/ (accessed September 23, 2013).

Jeffrey Passel, D'Vera Cohn, and Ana Gonzalez-Barrera. 2012. Net Migration from Mexico Falls to Zero—and Perhaps Less. Pew Hispanic Center. http://www.pewhispanic.org/2012/04/23/netmigration-from-mexico-falls-to-zero-and-perhaps-less/ (accessed September 12, 2013).

Jeffrey Passel, D’Vera Cohn, and Ana Gonzalez-Barrera. 2013. Population Decline of Unauthorized Immigrants Stalls, May Have Reversed. Pew Research Center's Hispanic Trends Project. http://www.pewhispanic.org/2013/09/23/references-16/ (accessed September 25, 2013).

Reyes, Belinda, Hans P. Johnson, and Richard Van Swearingen. 2002. Holding the line? The effect of the recent border build-up on unauthorized immigration. San Francisco: Public Policy Institute of California.

Rosenblum, Marc R. 2011. E-Verify: Strengths, weaknesses, and proposals for reform. Washington, DC: Migration Policy Institute.

Stark, Oded, and Marcin Jakubek. 2012. Employer sanctions and the welfare of native workers. Economics Letters 117:533-6.

Suskin, Alison, et al. 2006. Immigration enforcement within the United States. Washington, DC: Congressional Research Service.

Westat. 2009. Findings of the E-Verify program evaluation. Rockville, MD: Westat. http://www.uscis.gov/USCIS/E-Verify/E-Verify/Final E-Verify Report 12-16-09_2.pdf (accessed March 13, 2013). 
Table 1

Descriptive Statistics

\begin{tabular}{lcccc}
\hline & $\begin{array}{r}\text { Likely Unauthorized Mexican-Born } \\
\text { Immigrants }\end{array}$ & $\begin{array}{c}\text { U.S.-Born } \\
\text { Nispanics }\end{array}$ & $\begin{array}{c}\text { U.S.-Born White } \\
\text { Non-Hispanics }\end{array}$ \\
\hline Men: & 0.867 & 0.844 & 0.725 & 0.751 \\
Employed & 0.799 & 0.754 & 0.666 & 0.642 \\
Employed, wage \& salary & 0.068 & 0.089 & 0.059 & 0.108 \\
Self-employed & 0.064 & 0.059 & 0.091 & 0.062 \\
Unemployed & 0.931 & 0.902 & 0.817 & 0.813 \\
In labor force & 12.21 & 15.95 & 17.40 & 19.08 \\
Real hourly earnings & 0.033 & 0.023 & 0.026 & 0.022 \\
Switched employers since last month & 0.039 & 0.041 & 0.038 & 0.031 \\
E-Verify mandate & & & & \\
Women: & 0.039 & 0.043 & 0.034 & 0.029 \\
E-Verify mandate & 0.426 & 0.565 & 0.570 & 0.612 \\
Employed & 0.399 & 0.522 & 0.545 & 0.562 \\
Employed, wage \& salary & 0.026 & 0.042 & 0.024 & 0.049 \\
Self-employed & 0.055 & 0.044 & 0.065 & 0.042 \\
Unemployed & 0.481 & 0.608 & 0.635 & 0.654 \\
In labor force & 9.82 & 12.15 & 13.81 & 14.63 \\
Real hourly earnings & 0.027 & 0.018 & 0.023 & 0.020 \\
Switched employers since last month & 0.039 & 0.043 & 0.034 & 0.029 \\
E-Verify mandate & & & & \\
& & &
\end{tabular}


Note: Likely unauthorized immigrants are low-education (at most high school diploma) immigrants from Mexico who are not naturalized citizens. All groups only include low-education adults aged 20-64. The sample is from the 2002-2012 CPS. 
Table 2

The Effect of E-Verify Mandates on Labor Market Outcomes among Likely Unauthorized Mexican Immigrants

\begin{tabular}{lcc}
\hline & $\begin{array}{c}\text { Men } \\
(1)\end{array}$ & $\begin{array}{c}\text { Women } \\
(2)\end{array}$ \\
\hline Employed & 0.018 & $0.035^{*}$ \\
& $(0.018)$ & $(0.019)$ \\
Employed, wage \& salary & 0.023 & 0.027 \\
& $(0.028)$ & $(0.023)$ \\
Self employed & -0.005 & 0.008 \\
& $(0.014)$ & $(0.007)$ \\
Unemployed & -0.015 & -0.001 \\
& $(0.013)$ & $(0.010)$ \\
In labor force & 0.003 & $0.034^{*}$ \\
& $(0.007)$ & $(0.018)$ \\
Real hourly earnings & $-0.078^{* * *}$ & -0.012 \\
& $(0.018)$ & $(0.027)$ \\
Switched employers & -0.004 & 0.007 \\
& $(0.004)$ & $(0.008)$ \\
\hline
\end{tabular}

$* \mathrm{p}<0.1 ; * * \mathrm{p}<0.05 ; * * * \mathrm{p}<0.01$

Each cell represents a separate OLS regression. The natural log of real hourly earnings is used instead of the level of real hourly earnings. The regressions include controls for individual characteristics, the state business cycle, state and time fixed effects, and state-specific linear time trends. Standard errors are clustered on the state. 
Table 3

The Effect of E-Verify Mandates on Labor Market Outcomes among Likely Unauthorized Mexican Immigrants, by Years of U.S. Residence

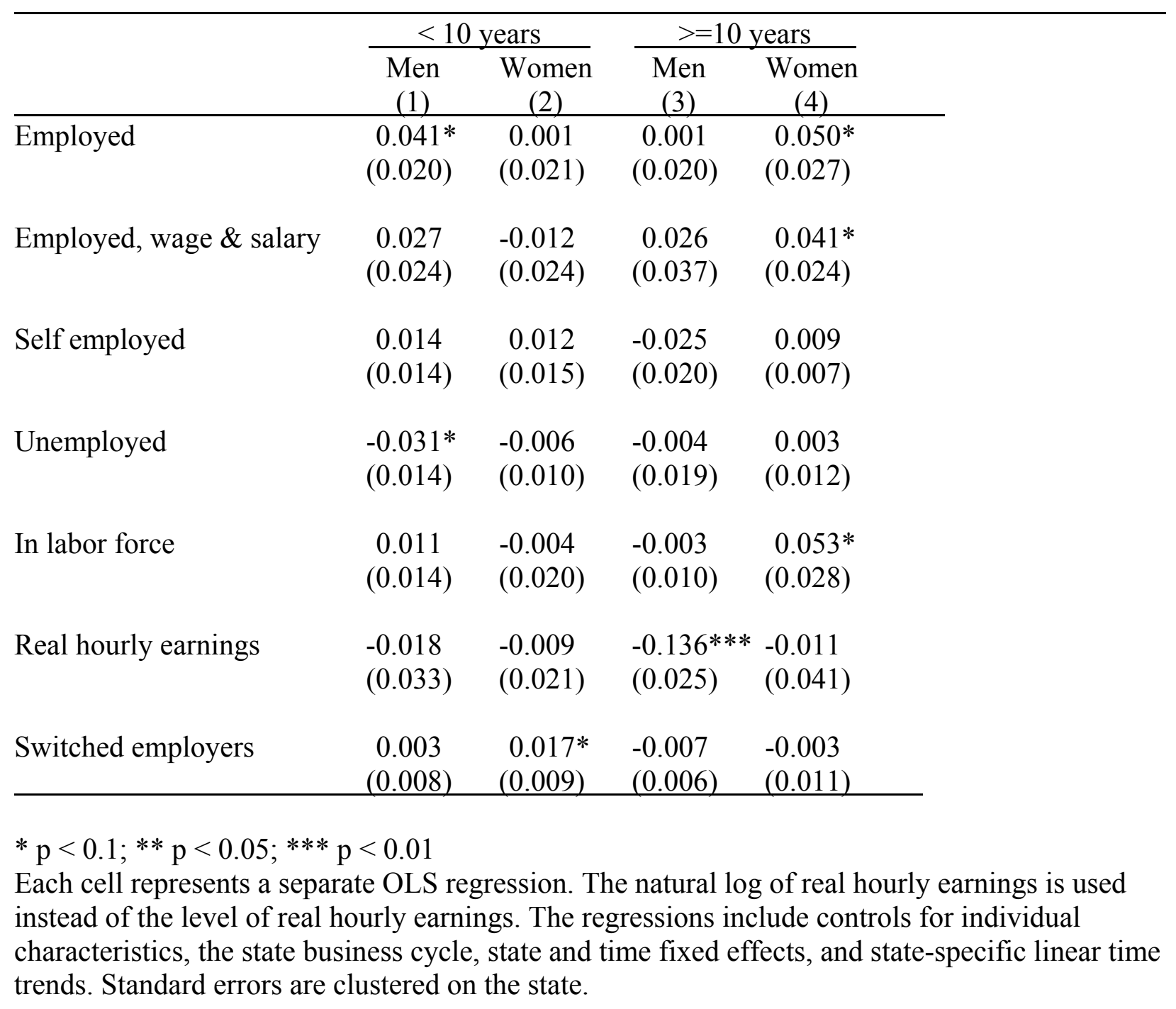


Table 4

The Effect of E-Verify Mandates on Labor Market Outcomes among Other Groups

\begin{tabular}{|c|c|c|c|c|c|c|}
\hline & \multicolumn{2}{|c|}{$\begin{array}{c}\text { Mexican-Born } \\
\text { Naturalized Citizens } \\
\end{array}$} & \multicolumn{2}{|c|}{$\begin{array}{l}\text { U.S.-Born } \\
\text { Hispanics }\end{array}$} & \multicolumn{2}{|c|}{$\begin{array}{l}\text { U.S.-Born White } \\
\text { Non-Hispanics }\end{array}$} \\
\hline & $\begin{array}{c}\text { Men } \\
(1) \\
\end{array}$ & $\begin{array}{c}\text { Women } \\
(2)\end{array}$ & $\begin{array}{l}\text { Men } \\
(3) \\
\end{array}$ & $\begin{array}{c}\text { Women } \\
(4)\end{array}$ & $\begin{array}{c}\text { Men } \\
(5) \\
\end{array}$ & $\begin{array}{c}\text { Women } \\
(6)\end{array}$ \\
\hline Employed & $\begin{array}{l}0.037^{*} \\
(0.020)\end{array}$ & $\begin{array}{l}-0.020 \\
(0.091)\end{array}$ & $\begin{array}{l}-0.011 \\
(0.037)\end{array}$ & $\begin{array}{c}0.023 \\
(0.018)\end{array}$ & $\begin{array}{c}0.006 \\
(0.009)\end{array}$ & $\begin{array}{c}0.005 \\
(0.008)\end{array}$ \\
\hline Employed, wage \& salary & $\begin{array}{l}0.098 * * * \\
(0.028)\end{array}$ & $\begin{array}{l}-0.009 \\
(0.106)\end{array}$ & $\begin{array}{l}-0.014 \\
(0.025)\end{array}$ & $\begin{array}{c}0.026 \\
(0.015)\end{array}$ & $\begin{array}{c}0.011 \\
(0.008)\end{array}$ & $\begin{array}{c}0.005 \\
(0.008)\end{array}$ \\
\hline Self employed & $\begin{array}{l}-0.058 * * \\
(0.025)\end{array}$ & $\begin{array}{l}-0.012 \\
(0.021)\end{array}$ & $\begin{array}{c}0.001 \\
(0.016)\end{array}$ & $\begin{array}{l}-0.001 \\
(0.007)\end{array}$ & $\begin{array}{l}-0.005 \\
(0.005)\end{array}$ & $\begin{array}{c}0.001 \\
(0.003)\end{array}$ \\
\hline Unemployed & $\begin{array}{l}-0.031 \\
(0.027)\end{array}$ & $\begin{array}{l}-0.025 \\
(0.017)\end{array}$ & $\begin{array}{l}0.044^{* *} \\
(0.020)\end{array}$ & $\begin{array}{l}-0.016 \\
(0.020)\end{array}$ & $\begin{array}{l}-0.004 \\
(0.004)\end{array}$ & $\begin{array}{l}-0.002 \\
(0.003)\end{array}$ \\
\hline In labor force & $\begin{array}{c}0.007 \\
(0.013)\end{array}$ & $\begin{array}{l}-0.045 \\
(0.077)\end{array}$ & $\begin{array}{c}0.033 \\
(0.021)\end{array}$ & $\begin{array}{c}0.007 \\
(0.020)\end{array}$ & $\begin{array}{c}0.002 \\
(0.006)\end{array}$ & $\begin{array}{c}0.003 \\
(0.008)\end{array}$ \\
\hline Real hourly earnings & $\begin{array}{l}0.070 * * \\
(0.034)\end{array}$ & $\begin{array}{c}0.071 \\
(0.054)\end{array}$ & $\begin{array}{l}0.085^{* * *} * \\
(0.025)\end{array}$ & $\begin{array}{l}-0.007 \\
(0.026)\end{array}$ & $\begin{array}{c}0.003 \\
(0.020)\end{array}$ & $\begin{array}{l}-0.014 \\
(0.019)\end{array}$ \\
\hline Switched employers & $\begin{array}{l}-0.003 \\
(0.014)\end{array}$ & $\begin{array}{c}0.004 \\
(0.007)\end{array}$ & $\begin{array}{c}0.005 \\
(0.005)\end{array}$ & $\begin{array}{c}0.005 \\
(0.007)\end{array}$ & $\begin{array}{c}0.001 \\
(0.002)\end{array}$ & $\begin{array}{l}-0.002 \\
(0.003)\end{array}$ \\
\hline
\end{tabular}

$* \mathrm{p}<0.1 ; * * \mathrm{p}<0.05 ; * * * \mathrm{p}<0.01$

Each cell represents a separate OLS regression. The natural log of real hourly earnings is used instead of the level of real hourly earnings. The regressions include controls for individual characteristics, the state business cycle, state and time fixed effects, and state-specific linear time trends. Standard errors are clustered on the state. 


\begin{tabular}{|c|c|c|c|}
\hline State & Adoption Date & Implementation Date & Comments \\
\hline Alabama & June 2011 & April 2012 & $\begin{array}{l}\text { Government contractors only in Jan- } \\
\text { Mar } 2012\end{array}$ \\
\hline Arizona & July 2007 & January 2008 & \\
\hline Georgia & May 2011 & January 2012 & Size phase in \\
\hline Mississippi & March 2008 & July 2008 & Size phase in \\
\hline North Carolina & June 2011 & October 2012 & Size phase in \\
\hline South Carolina & June 2011 & January 2012 & Size phase in \\
\hline Tennessee & June 2011 & January 2012 & \\
\hline Utah & March 2010 & July 2010 & $\begin{array}{l}\text { Public employers and government } \\
\text { contractors only in July 2009-June } \\
2010\end{array}$ \\
\hline
\end{tabular}

Source: Based on http://www.troutmansanders.com/immigration/. Government contractors means businesses with state contracts (and their subcontractors in most states; conditional on contract size in some states). Only laws that require use of E-Verify and do not offer another option, such as certifying or affirming employment eligibility, are listed here. Policies that apply to only public agencies or government contractors are not listed here. 